\title{
KORELASI TAHANAN UJUNG KONUS (qc) DENGAN CALIFORNIA BEARING RATIO (CBR) UNTUK TANAH DI BANJARBARU
}

\author{
Hendra Cahyadi \\ Program Studi Teknik Sipil Universitas Islam Kalimantan MAB \\ Email: irarizqonroyan@gmail.com
}

\begin{abstract}
ABSTRAK
Selama ini untuk mendapatkan harga CBR berdasarkan nilai $\mathrm{q}_{c}$, umumnya perencana merujuk pada grafik/nomogram yang dipublikasikan pada buku-buku literatur, dimana grafik/nomogram tersebut belum tentu dapat diaplikasikan pada semua daerah termasuk di Banjarbaru. Pada penelitian ini diharapkan di dapat grafik atau persamaan antara CBR dan uji konus dengan luan permukaan konus sebesar 0,5 in $^{2}$. Kedua uji tersebut akan menggunakan sampel yang mempunyai kadar air dan kepadatan yang sama. Pengambilan sampel tanah dilakukan di empat lokasi yang ada di daerah Banjarbaru yaitu Balitra, Jalan Semeru, Sirkuit Mandiangin, dan Komplek Banjarbaru Asri. Srtiap lokasi diambil tiga titik sampel tanah. Dari pengujian tersebut, didapatkan hubungan antara CBR dan tahanan ujung konus $\left(\mathrm{q}_{\mathrm{c}}\right)$ untuk daerah Banjarbaru yaitu: $\mathrm{CBR}=0,0545 \mathrm{q}_{\mathrm{c}}+2,618$ dengan harga $\mathrm{q}_{\mathrm{c}}$ berkisar antara $50 \mathrm{~kg} / \mathrm{cm}^{2}$ sampai $300 \mathrm{~kg} / \mathrm{cm}^{2}$.
\end{abstract}

Kata Kunci: CBR, qc, pemadatan, kadar air

\begin{abstract}
All this time, the score of CBR is calculated according to $q_{c}$ score. Generally, planner usually refers to graph $/$ nomogram which published on literature book, but the graph / nomogram on the book may not probably able to apply in all areas, including Banjarbaru. In this particular research, it aimed to make the graph or equation between CBR and Cone test in the cone area of $0.5 \mathrm{in}^{2}$. The both tests used the same sample of water contents and density. The samples were taken in four areas in Banjarbaru; Balitra, Jalan Semeru (Semeru Street), Mandiangin Circuit, and Banjarbaru Asri Housing. There took soil samples in three points of every areas. By the test, obtained the correlation between CBR and Cone End Resistance $\left(q_{c}\right)$ on Banjarbaru area: $C B R=0.0545 q c+2.618$ and the $q_{c}$ score is between $50 \mathrm{~kg} / \mathrm{cm}^{2}$ to $300 \mathrm{~kg} / \mathrm{cm}^{2}$.
\end{abstract}

Keywords: $C B R, q_{c}$, compaction, water content

\section{PENDAHULUAN}

\section{Latar Belakang}

Pemeriksaan harga CBR biasanya dikerjakan dalam waktu yang relatif lama jika melalui uji laboratorium. Untuk mempersingkat waktu, biasanya perencana melakukan tes CBR langsung di lapangan. Jenis uji CBR yang baku adalah dengan menggunakan piston. Karena penampang piston ukurannya relatif besar agak besar, maka diperlukan beban yang cukup besar agar piston tersebut bias masuk ke dalam tanah pada kedalaman yang diinginkan. Uji lainnya adalah dengan menggunakan alat konus. Dibandingkan dengan uji piston, pemeriksaan dengan cara ini lebih mudah. Ujung konus yang lancip memudahkan alat ini untuk dimasukkan ke dalam tanah sehingga pembebanan yang diperlukan lebih kecil dibandingkan bila 
menggunakan piston. Dalam pemeriksaan ini, diperlukan data tahanan ujung konus serta korelasi (hubungan) antara tahanan ujung konus dengan CBR.

Sebenarnya, grafik korelasi antara CBR dan tahanan ujung konus sudah ada, yaitu yang dihasilkan dari hasil penelitian yang dilakukan oleh Bakrie Oemar dan Nurly Gofar tahun 1995. Tetapi grafik tersebut berasal dari daerah yang tidak diketahui, yang tentunya struktur dan sifat tanahnya kemungkinan besar berbeda.

Sedangkan grafik hubungan tahanan ujung konus dengan CBR untuk daerah Banjarbaru belum ada. Hal inilah yang membuat perencana sering melakukan uji CBR di laboratorium atau cenderung langsung memperbesar faktor keamanan dalam rancangannya yang tentunya mengakibatkan peningkatan biaya proyek. Kondisi inilah yang menjadi latar belakang penelitian untuk mencari hubungan antara tahanan ujung konus dengan CBR khususnya untuk tanah di daerah Banjarbaru.

\section{Rumusan Masalah}

Untuk mengetahui tujuan penelitian, terlebih dahulu diuraikan rumusan masalahnya yaitu

1. Berapakah nilai tahanan ujung konus $\left(\mathrm{q}_{\mathrm{c}}\right)$ untuk tanah di Banjarbaru?

2. Berapakah harga CBR untuk tanah di Banjarbaru?

3. Bagaimanakah korelasi nilai $\mathrm{CBR}$ dan $\mathrm{q}_{\mathrm{c}}$ untuk tanah di Banjarbaru?

\section{Tujuan Penelitian}

Untuk menjawab pertanyaan - pertanyaan di atas, maka dirumuskan tujuan dari penelitian ini, yaitu :

1. Menentukan nilai nilai tahanan ujung konus $\left(\mathrm{q}_{\mathrm{c}}\right)$ untuk tanah di Banjarbaru.

2. Menentukan nilai CBR untuk tanah di Banjarbaru.

3. Menentukan korelasi antara nilai CBR dan $\mathrm{q}_{\mathrm{c}}$ untuk tanah di Banjarbaru

\section{KAJIAN PUSTAKA}

\section{California Bearing Ratio}

Uji CBR berasal dari Departemen Transportasi California tahun 1929. Uji ini dimaksudkan untuk menentukan kelayakan suatu lapisan yanah yang akan digunakan sebagai subbase atau base course dalam konstruksi jalan raya. Harga CBR adalah perbandingan antara beban penetrasi suatu bahan terhadap bahan standar dengan kedalaman dan kecepatan penetrasi yang sama. Tabel harga dari tegangan baku adalah seperti pada Tabel 1 di bawah ini.

Tabel 1. Harga Tegangan Baku Untuk Setiap Penetrasi

\begin{tabular}{cccc}
\hline \multicolumn{2}{c}{ Penetrasi } & \multicolumn{2}{c}{$\begin{array}{c}\text { Satuan tegangan } \\
\text { baku }\end{array}$} \\
\hline $\mathrm{mm}$ & inch & $\mathrm{Mpa}$ & Psi \\
\hline 2.5 & 0.10 & 6.9 & 100 \\
\hline 5.0 & 0.20 & 10.3 & 1500 \\
\hline 7.5 & 0.30 & 13.0 & 1900 \\
\hline 10.0 & 0.40 & 16.0 & 2300 \\
\hline 12.7 & 0.50 & 18.0 & 2600 \\
\hline \multicolumn{2}{l}{ Sumber: Bowles (1992) } \\
\end{tabular}

Harga CBR digunakan untuk menilai kemampuan tanah, utamanya untuk digunakan sebagai base atau subbase di bawah perkerasan jalan atau lapangan terbang. Tabel 2 di bawah ini merupakan tipikal rating dari harga CBR.

Tabel 2. Klasifikasi Tanah Berdasarkan Harga CBR

\begin{tabular}{|c|c|c|c|c|}
\hline \multirow{2}{*}{$\begin{array}{c}\text { CBR } \\
\text { No }\end{array}$} & \multirow{2}{*}{$\begin{array}{l}\text { Tingka } \\
\text { tan } \\
\text { Umum }\end{array}$} & \multirow[b]{2}{*}{ Kegunaan } & \multicolumn{2}{|c|}{ Klasifikasi } \\
\hline & & & Unified & AASHTO \\
\hline $0-3$ & $\begin{array}{l}\text { Very } \\
\text { poor }\end{array}$ & Subgrade & $\begin{array}{l}\mathrm{OH}, \mathrm{CH} \text {, } \\
\mathrm{MH}, \mathrm{OL}\end{array}$ & $\mathrm{A} 5, \mathrm{~A} 6, \mathrm{~A} 7$ \\
\hline $3-7$ & $\begin{array}{l}\text { Poor to } \\
\text { fair }\end{array}$ & Subgrade & $\begin{array}{l}\mathrm{OH}, \mathrm{CH}, \\
\mathrm{MH}, \mathrm{OL}\end{array}$ & $\begin{array}{l}\text { A4,A5,A6 } \\
\text {,A7 }\end{array}$ \\
\hline $7-20$ & Fair & Subbase & $\begin{array}{l}\text { OL,CL, } \\
\text { ML,SC, } \\
\text { SM,SP }\end{array}$ & $\begin{array}{l}\text { A2,A4,A6 } \\
\text {,A7 }\end{array}$ \\
\hline $\begin{array}{l}20- \\
50\end{array}$ & Good & $\begin{array}{l}\text { Base or } \\
\text { subbase }\end{array}$ & $\begin{array}{l}\text { GM,GC, } \\
\text { SW,SM, } \\
\text { SP,GP }\end{array}$ & $\begin{array}{l}\mathrm{Ab}, \mathrm{A} 2- \\
5, \mathrm{~A} 3, \mathrm{~A} 2- \\
6\end{array}$ \\
\hline$>50$ & $\begin{array}{l}\text { Excell } \\
\text { ent }\end{array}$ & Base & & $\begin{array}{l}\text { A1a,A2- } \\
4, A 3\end{array}$ \\
\hline
\end{tabular}

Sumber: Bowles (1992) 


\section{Uji CBR Laboratorium}

Uji ini menggunakan alat penetrasi dengan kapasitas sekurang-kurangnya 4,45 ton dengan kecepatan penetrasi sebesar $1,25 \mathrm{~mm}$ per menit. Untuk uji CBR di laboratorium diperlukan uji pemadatan. Biasanya contoh tanah yang diambil untuk uji CBR di laboratorium adalah contoh tanah yang berada dalam kadar air optimum. Tetapi pemeriksaan CBR bisa saja dilakukan pada beberapa macam kadar air dan berat isi kering yang berbeda. Kerugian dari penggunaan uji CBR laboratorium adalah:

Perlu waktu yang relatif lebih lama bila dibanding dengan uji langsung di lapangan, karena harus melalui prosedur - prosedur pengujian antara lain: penyaringan, Atterberg limit test, dan pemadatan.

$>$ Perlu biaya lebih diantaranya biaya pengambilan dan angkut contoh tanah ke laboratorium.

\section{Uji CBR lapangan}

Dibanding dengan uji laboratorium, uji CBR langsung di lapangan lebih menguntungkan dari segi waktu ( data bisa didapat saat itu juga ), dan tidak memerlukan pengambilan sampel tanah. Beberapa uji CBR yang biasa dilakukan di lapangan antara lain yang pertama adalah uji piston. Uji ini antara lain menggunakan dongkrak CBR mekanis dengan kapasitas 10 ton, juga memerlukan sebuah truk atau kendaraan berat lainnya yang dibebani sesuai dengan kebutuhan dan dibawahnya dipasang sebuah dongkrak mekanis. Kerugian dari uji ini adalah penggunaan truk atau kendaraan sejenis yang membuat uji ini jadi kurang efisien.

Uji CBR lapangan yang lain adalah uji konus atau Cone Penetrometer. Cone Penetrometer dikembangkan oleh U.S Army Corps of Engineers untuk memperkirakan kapasitas daya dukung tanah kohesif yang akan dilewati oleh kendaraan tempur. Cone Penetrometer mempunyai dua model yaitu model militer dan model komersial, terdiri dari pegangan, proving ring, dan dial gauge. Konusnya berupa stainless steel dengan tinggi 1,5 inch dan mempunyai luas 0,5 inch $^{2}$.

Beberapa keuntungan dari uji ini adalah :
Sangat cepat, terutama bila digunakan peralatan elektronik untuk mencatat tahanan ujung.

Memungkinkan untuk pencatatan yang menerus atas tahanan tanah pada lapisan lapisan yang ingin diselidiki.

$>$ Tidak memerlukan pembebanan khusus karena ujung konus yang lancip memudahkan konus untuk dipenetrasikan.

\section{METODE PENELITIAN}

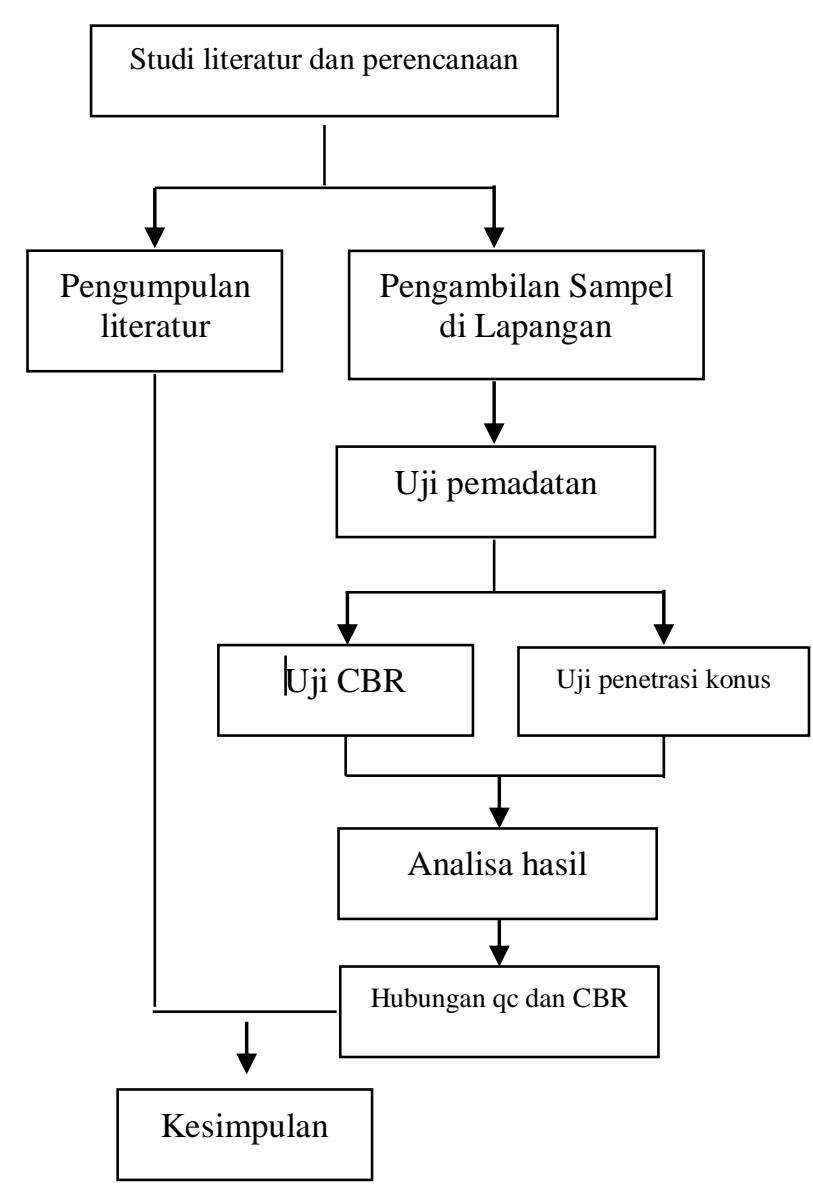

Gambar 1. Bagan Alir Penelitian

Langkah-langkah dalam penelitian dapat dilihat pada Gambar 1.

\section{Pekerjaan Lapangan}

Pengambilan contoh tanah dilakukan di daerah Jalan Semeru, Komplek Banjarbaru Asri, Balitra, dan di Sirkuit Mandiangin. Dari masing masing lokasi diambil tiga sampel tanah. 


\section{Pekerjaan Laboratorium}

\section{Uji Sifat Fisik Tanah}

Dalam pemeriksaan ini akan dicari harga batas cair ( LL ), batas plastis ( PL ) dan berat jenis ( Gs ). Standar ASTM D-4318 digunakan untuk uji batas plastis dan batas cair, sedangkan ASTM D854 digunakan untuk uji berat jenis.

\section{Uji Pemadatan}

Langkah-langkah pekerjaan pemadatan adalah sebagai berikut:

1. Sebelum melakukan uji pemadatan, terlebih dahulu diperiksa kadar air awal.

2. Dari hasil uji batas plastis dan batas cair akan didapatkan harga kadar air optimum.

3. Benda uji dibagi dalam lima bagian yaitu satu bagian dengan kadar air optimum, dua bagian dengan kadar air di bawah kadar air optimum, dua bagian di atas kadar air optimum. Penambahan air untuk mencapai kadar air yang diinginkan harus memperhitungkan harga kadar air alami.

4. Harga zero air void di dapat berdasarkan harga berat jenis ( Gs ) tanah.

5. Waktu pencampuran. Lebih lama tanah dicampur akan lebih tinggi kerapatan maksimum yang diperoleh, karena apabila tanah lebih lama dicampur maka struktur lempung akan lebih tersebar.

Prosedur uji pemadatan adalah menurut standar ASTM D 698-78

\section{Uji CBR dan Uji Penetrasi Konus}

Contoh tanah yang mempunyai kepadatan sama, akan diuji dengan 2 jenis pengujian yaitu uji CBR dan uji penetrasi. Untuk uji CBR, sampel tanah akan diperiksa dengan penetrasi dimana kecepatan penetrasi yang baku adalah 1,25 $\mathrm{mm} /$ det. Harga CBR diambil dari harga penetrasi $2,5 \mathrm{~mm}$. Bila harga yang didapat pada penetrasi 5 $\mathrm{mm}$ ternyata lebih besar, maka percobaan diulang lagi. Bila percobaan ulang ini masih tetap menghasilkan nilai CBR pada penetrasi $5 \mathrm{~mm}$ lebih besar dari nilai CBR pada penetrasi $2,5 \mathrm{~mm}$, maka harga CBR untuk penetrasi $5 \mathrm{~mm}$ yang dipakai. Prosedur uji CBR adalah menurut standar ASTM 1883-87. Sedangkan untuk uji penetrasi, konus akan diletakkan pada alat penetrasi untuk menggantikan piston. Kemudian konus ditekan ke dalam sampel tanah dimana kedalaman penetrasi dan kepadatan tanahnya sama dengan uji CBR.

Yang perlu diperhatikan dalam uji CBR dan uji konus adalah :

1. Tercapainya bidang sentuh yang sempurna antara permukaan piston dan konus dengan permukaan tanah yang akan diuji. Maka diharuskan permukaan tanah yang akan diuji betul-betul rata.

2. Pemberian perilaku yang sama untuk contoh tanah yang akan diuji dengan uji CBR dan uji penetrasi konus seperti energi penumbukan, penambahan air, waktu pencampuran, dan lain-lain. Hal ini untuk menjamin tercapainya kepadatan yang sama untuk contoh tanah yang akan diuji hingga korelasi antara harga CBR dan tahanan ujung konus yang dihasilkan akan bisa dipertanggungjawabkan.

\section{Analisis Statistik}

Setelah semua uji CBR dan konus selesai dilakukan, maka data-data yang didapatkan akan dianalisa dengan metode statistic yaitu dengan cara least square atau garis kuadrat minimum. Dari satu titik contoh tanah dengan kepadatan yang sama akan didapatkan variabel $\mathrm{X}$ untuk tahanan ujung konus dan variabel $\mathrm{Y}$ untuk harga CBR. Hal demikian digunakan untuk titik-titik contoh tanah yang lain, maka akan didapat harga X1, Y1; X2, $\mathrm{Y} 2$; X3, Y3.....;Xn , Yn. Dari masing-masing lokasi didapatkan sebuah grafik. Grafik - grafik tersebut kemudian diperiksa apakah mempunyai korelasi yang kuat atau tidak yang ditandai dengan harga $\mathrm{R}$ atau koefisien determinasi. Harga $\mathrm{R}$ menunjukkan ukuran hubungan linier antara dua perubah $\mathrm{X}$ dan $\mathrm{Y}$. semakin tinggi harga $\mathrm{R}$, maka makin kuatlah korelasi antara $\mathrm{X}$ dan $\mathrm{Y}$. Kalau korelasi masing - masing lokasi sudah kuat, grafik - grafik tersebut bisa digabung untuk mendapatkan grafik korelasi CBR dengan $\mathrm{q}_{\mathrm{c}}$ untuk daerah Banjarbaru.

\section{ANALISA DATA}

\section{Atribut Tanah}

Dari uji sifat fisis tanah didapatkan hasil sebagaimana Tabel 3: 
Tabel 3 Klasifikasi Tanah Banjarbaru

\begin{tabular}{lccc}
\hline \multicolumn{1}{c}{ Lokasi } & Titik & $\begin{array}{c}\text { Simbol } \\
\text { Klasifikasi } \\
\text { Tanah }\end{array}$ & Gs \\
\hline Balitra & 1 & CL & 2.73 \\
\hline Balitra & 2 & CL & 2.70 \\
\hline Balitra & 3 & CL & 2.77 \\
\hline $\begin{array}{l}\text { Sirkuit } \\
\text { Mandiangin }\end{array}$ & 1 & ML & 2.68 \\
\hline $\begin{array}{l}\text { Sirkuit } \\
\text { Mandiangin }\end{array}$ & 2 & ML & 2.67 \\
\hline $\begin{array}{l}\text { Sirkuit } \\
\text { Mandiangin }\end{array}$ & 3 & ML & 2.70 \\
\hline Jalan Semeru & 1 & CL & 2.78 \\
\hline Jalan Semeru & 2 & CL & 2.72 \\
\hline Jalan Semeru & 3 & CL & 2.70 \\
\hline $\begin{array}{l}\text { Komp. } \\
\text { Banjarbaru } \\
\text { Asri }\end{array}$ & 1 & CL & 2.73 \\
\hline $\begin{array}{l}\text { Komp. } \\
\text { Banjarbaru } \\
\text { Asri }\end{array}$ & 2 & CL & 2.77 \\
\hline $\begin{array}{l}\text { Komp. } \\
\text { Banjarbaru } \\
\text { Asri }\end{array}$ & 3 & CL & 2.71 \\
\hline & & & \\
\hline
\end{tabular}

\section{Uji CBR dan Uji Konus}

Dari hasil uji CBR dan konus didapat hasil seperti pada Tabel 4 di bawah ini

Tabel 4 Harga CBR dan Tahanan Ujung Konus Untuk Tanah di Balitra

\begin{tabular}{ccccc}
\hline Lokasi & Titik & $\begin{array}{c}\text { Kadar } \\
\text { Air }(\%)\end{array}$ & $\begin{array}{c}\text { CBR } \\
(\%)\end{array}$ & $\begin{array}{c}\mathrm{q}_{\mathrm{c}} \\
\left(\mathrm{kg} / \mathrm{cm}^{2}\right)\end{array}$ \\
\hline & & 7.68 & 9.0 & 108.905 \\
Balitra & 1 & 10.64 & 8.3 & 107.906 \\
& & 13.50 & 15.9 & 196.829 \\
& & 18.29 & 14.9 & 256.777 \\
& & 8.19 & 5.8 & 54.952 \\
\hline Balitra & 2 & 10.41 & 7.4 & 105.908 \\
& & 13.25 & 14.1 & 195.917 \\
& & 18.03 & 13.6 & 215.813 \\
& & 8.15 & 7.9 & 69.939 \\
\hline \multirow{3}{*}{ Balitra } & 3 & 10.38 & 6.9 & 88.923 \\
& & 13.28 & 13.5 & 198.827 \\
& & 18.03 & 12.5 & 168.853 \\
& & & 4.6 & 48.957 \\
\hline
\end{tabular}

Dari hasil uji laboratorium didapatkan hasil CBR untuk lokasi Balitra berkisar antara $5,2 \%$ - $15,9 \%$ dan nilai tahanan ujung konus berkisar antara 49,947 kg/cm2 - 215,813 kg/cm2. Grafik hubungan antara harga CBR dan harga tahanan ujung konus untuk lokasi Balitra adalah se bagai berikut:

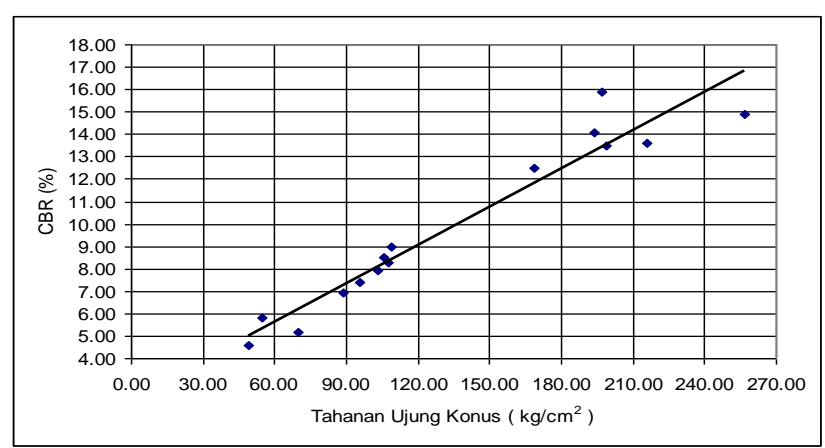

Gambar 2 Grafik Hubungan Harga CBR dan Tahanan Ujung Konus Lokasi Balitra

Dari Gambar 2 terlihat kecenderungan bahwa makin tinggi harga $\mathrm{q}_{\mathrm{c}}$ makin tinggi pula harga CBR. Penyebaran titik - titik terlihat membentuk garis linier positif dengan persamaan CBR $=0,0565 \mathrm{q}_{\mathrm{c}}+2,289$ dan hubungan linier antara harga CBR dan $\mathrm{q}_{\mathrm{c}}$ adalah sangat baik atau sangat tinggi. Dengan $\mathrm{R}^{2}=0,9323$, bisa dikatakan bahwa 93,23\% diantara keragaman dalam nilainilai CBR dapat dijelaskan oleh hubungan linearnya dengan harga $\mathrm{q}_{\mathrm{c}}$

Tabel 5 Harga CBR dan Tahanan Ujung Konus Untuk Tanah di Sirkuit Mandiangin

\begin{tabular}{ccccc}
\hline Lokasi & Titik & $\begin{array}{c}\text { Kadar } \\
\text { Air } \\
(\%)\end{array}$ & $\begin{array}{c}\text { CBR } \\
(\%)\end{array}$ & $\begin{array}{c}\mathrm{qc}( \\
\left.\mathrm{kg} / \mathrm{cm}^{2}\right)\end{array}$ \\
\hline & & 10.26 & 18.2 & 299.74 \\
Sirkuit & 1 & 13.17 & 15.2 & 269.766 \\
Mandiangin & 1 & 15.57 & 16.1 & 209.818 \\
& & 19.37 & 13.9 & 192.832 \\
& & 12.45 & 13.3 & 196.829 \\
\hline Sirkuit & 2 & 14.76 & 13.6 & 203.823 \\
Mandiangin & 2 & 19.05 & 17.2 & 229.800 \\
& & 20.97 & 13.0 & 189.835 \\
& & 12.38 & 12.2 & 170.852 \\
\hline Sirkuit & 3 & 14.80 & 14.6 & 180.843 \\
Mandiangin & & 16.87 & 16.6 & 267.767 \\
& & 18.92 & 12.0 & 165.856 \\
& & 21.00 & 11.6 & 156.864 \\
\hline
\end{tabular}

Dari uji laboratorium didapatkan harga CBR antara $11,6 \%$ - 17,2\%, sedangkan dari pembacaan konus didapatkan nilai antara 109,905 $\mathrm{kg} / \mathrm{cm}^{2}-299,740 \mathrm{~kg} / \mathrm{cm}^{2}$. Grafik hubungan antara 
CBR dan tahanan ujung konus untuk lokasi Sirkuit Mandiangin adalah sebagai berikut :

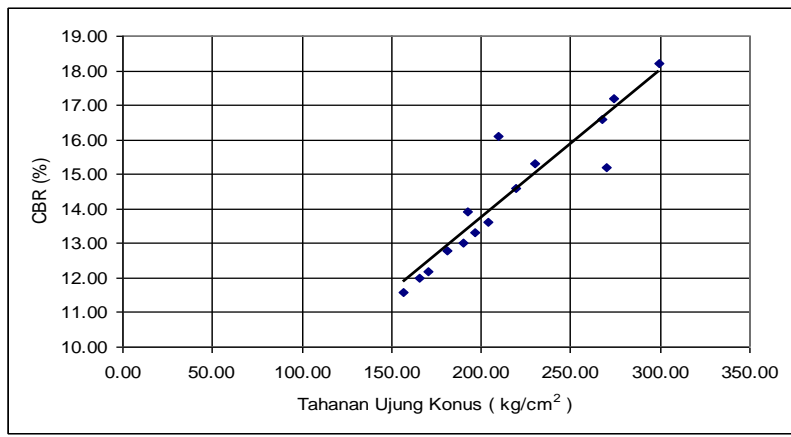

Gambar 3 Hubungan CBR dan Tahanan Ujung Konus Lokasi Sirkuit Mandiangin

Dari Gambar 3 terlihat kecenderungan bahwa makin tinggi harga $\mathrm{q}_{\mathrm{c}}$ makin tinggi pula harga CBR. Penyebaran titik - titik terlihat membentuk garis linier positif dengan persamaan $\mathrm{CBR}=0,0427 \mathrm{q}_{\mathrm{c}}+5,1809$ dan hubungan linier antara harga CBR dan $\mathrm{q}_{\mathrm{c}}$ adalah sangat baik atau sangat tinggi. Dengan $\mathrm{R}^{2}=0,8825$, bisa dikatakan bahwa $88,25 \%$ diantara keragaman dalam nilainilai CBR dapat dijelaskan oleh hubungan linearnya dengan harga $\mathrm{q}_{\mathrm{c}}$

Tabel 6 Harga CBR dan Tahanan Ujung Konus Untuk Tanah di Jalan Semeru

\begin{tabular}{ccccc}
\hline Lokasi & Titik & $\begin{array}{c}\text { Kadar } \\
\text { Air }(\%)\end{array}$ & $\begin{array}{c}\text { CBR } \\
(\%)\end{array}$ & $\begin{array}{c}\mathrm{qc}( \\
\left.\mathrm{kg} / \mathrm{cm}^{2}\right)\end{array}$ \\
\hline & & 9.86 & 11.7 & 146.872 \\
Jalan & 1 & 12.65 & 13.0 & 189.835 \\
Semeru & 1 & 15.47 & 17.9 & 270.765 \\
& & 17.85 & 8.7 & 104.909 \\
& & 20.36 & 7.4 & 98.914 \\
\hline & & 10.14 & 11.1 & 152.867 \\
Jalan & & 12.75 & 14.0 & 210.817 \\
Semeru & 2 & 15.58 & 16.9 & 268.767 \\
& & 17.99 & 8.1 & 105.908 \\
& & 20.01 & 6.8 & 103.910 \\
\hline & & 10.05 & 11.0 & 136.861 \\
Jalan & 3 & 12.44 & 13.4 & 196.829 \\
Semeru & 3 & 15.43 & 14.2 & 218.810 \\
& & 17.88 & 6.9 & 90.921 \\
& & 19.94 & 6.1 & 88.923 \\
\hline
\end{tabular}

Dari uji laboratorium didapatkan harga CBR antara 6,1\% - 17,9\%, sedangkan dari pembacaan konus didapatkan nilai antara 88,923 $\mathrm{kg} / \mathrm{cm}^{2}-270,765 \mathrm{~kg} / \mathrm{cm}^{2}$. Grafik hubungan antara CBR dan tahanan ujung konus untuk lokasi Jalan Semeru adalah sebagai berikut:

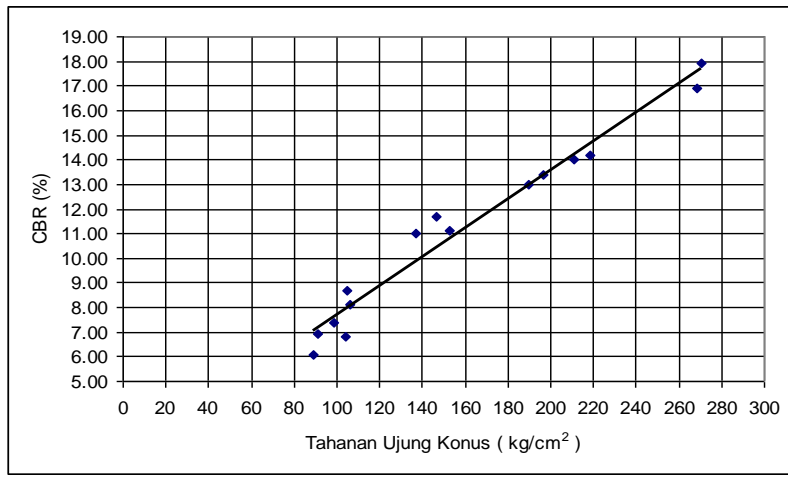

Gambar 4 Hubungan CBR dan Tahanan Ujung Konus Lokasi Jalan Semeru

Dari Gambar 4 terlihat kecenderungan bahwa makin tinggi harga $\mathrm{q}_{\mathrm{c}}$ makin tinggi pula harga CBR. Penyebaran titik - titik terlihat membentuk garis linier positif dengan persamaan $\mathrm{CBR}=0,0584 \mathrm{q}_{\mathrm{c}}+1,8747$ dan hubungan linier antara harga CBR dan $\mathrm{q}_{\mathrm{c}}$ adalah sangat baik atau sangat tinggi. Dengan $\mathrm{R}^{2}=0,9642$, bisa dikatakan bahwa $96,42 \%$ diantara keragaman dalam nilainilai CBR dapat dijelaskan oleh hubungan linearnya dengan harga $\mathrm{q}_{\mathrm{c}}$

Tabel 7 Harga CBR dan Tahanan Ujung Konus Untuk Tanah di Komplek Banjarbaru Asri

\begin{tabular}{ccccc}
\hline Lokasi & Titik & $\begin{array}{c}\text { Kadar } \\
\text { Air } \\
(\%)\end{array}$ & $\begin{array}{c}\text { CBR } \\
(\%)\end{array}$ & $\begin{array}{c}\mathrm{qc}( \\
\left.\mathrm{kg} / \mathrm{cm}^{2}\right)\end{array}$ \\
\hline & & 20.10 & 13.7 & 181.842 \\
Komp. & & 18.57 & 14.3 & 202.824 \\
Banjarbaru & 1 & 15.73 & 16.8 & 268.767 \\
Asri & & 12.76 & 16.3 & 248.784 \\
& & 9.82 & 16.2 & 215.813 \\
\hline & & 11.79 & 13.1 & 241.790 \\
Komp. & & 13.80 & 15.7 & 241.790 \\
Banjarbaru & 2 & 16.00 & 16.2 & 253.780 \\
Asri & & 18.12 & 15.6 & 199.826 \\
& & 19.73 & 13.6 & 190.834 \\
\hline & & 10.40 & 15.0 & 227.802 \\
Komp. & & 13.35 & 15.1 & 229.800 \\
Banjarbaru & 3 & 15.86 & 15.6 & 246.786 \\
Asri & & 17.87 & 13.0 & 190.834 \\
& & 19.95 & 12.5 & 173.849 \\
\hline
\end{tabular}

Dari uji laboratorium didapatkan harga CBR antara $12,5 \%$ - $16,3 \%$, sedangkan dari pembacaan konus didapatkan nilai antara 173,849 $\mathrm{kg} / \mathrm{cm}^{2}-268,767 \mathrm{~kg} / \mathrm{cm}^{2}$. Grafik hubungan antara CBR dan tahanan ujung konus untuk lokasi Komplek Banjarbaru Asri adalah sebagai berikut : 


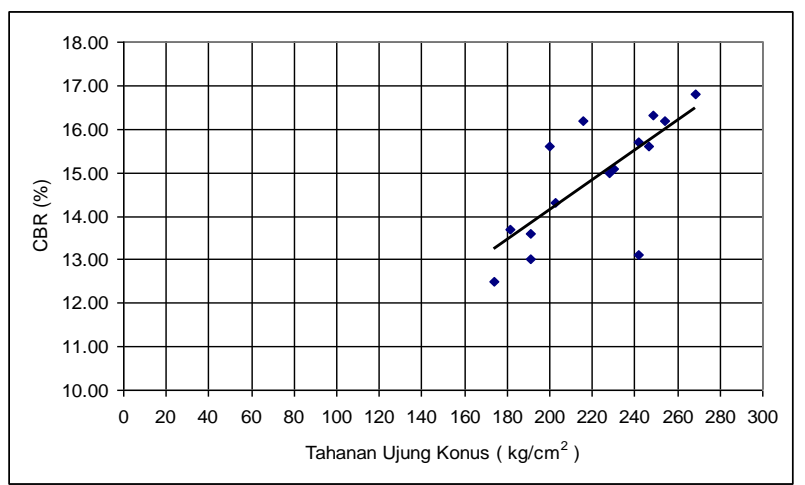

Gambar 5 Hub CBR dan Tahanan Ujung Konus Lokasi Komp Banjarbaru Asri

Dari Gambar 5 terlihat kecenderungan bahwa makin tinggi harga $\mathrm{q}_{\mathrm{c}}$ makin tinggi pula harga CBR. Penyebaran titik - titik terlihat membentuk garis linier positif dengan persamaan $\mathrm{CBR}=0,0344 \mathrm{q}_{\mathrm{c}}+7,2514$ dan hubungan linier antara harga CBR dan $\mathrm{q}_{\mathrm{c}}$ adalah cukup baik. Dengan $\mathrm{R}^{2}=0,5331$, bisa dikatakan bahwa $53,31 \%$ diantara keragaman dalam nilai-nilai CBR dapat dijelaskan oleh hubungan linearnya dengan harga $\mathrm{q}_{\mathrm{c}}$

\section{Hubungan $q_{c}$ dan CBR Untuk Daerah Banjarbaru}

Setelah didapatkan hubungan antara CBR dan tahanan ujung konus untuk masing - masing lokasi, maka selanjutnya hasilnya diplotkan menjadi satu grafik yang menggambarkan hubungan CBR dan tahanan ujung konus untuk wilayah Banjarbaru secara keseluruhan. Dari Gambar 6 terlihat bahwa kecenderungan makin tinggi harga $\mathrm{q}_{\mathrm{c}}$ makin tinggi pula harga CBR. Penyebaran titik - titik membentuk garis linear positif dengan persamaan $\mathrm{CBR}=0,0545 \mathrm{q}_{\mathrm{c}}+$ 2,618 yang mempunyai hubungan linear yang sangat baik atau sangat tinggi antara harga CBR dan $\mathrm{q}_{\mathrm{c}}$. Harga $\quad \mathrm{R}^{2}=0,9325$ menunjukkan bahwa 93,25\% diantara keragaman dalam nilai nilai CBR dapat dijelaskan oleh hubungan linearnya dengan harga $\mathrm{q}_{\mathrm{c}}$

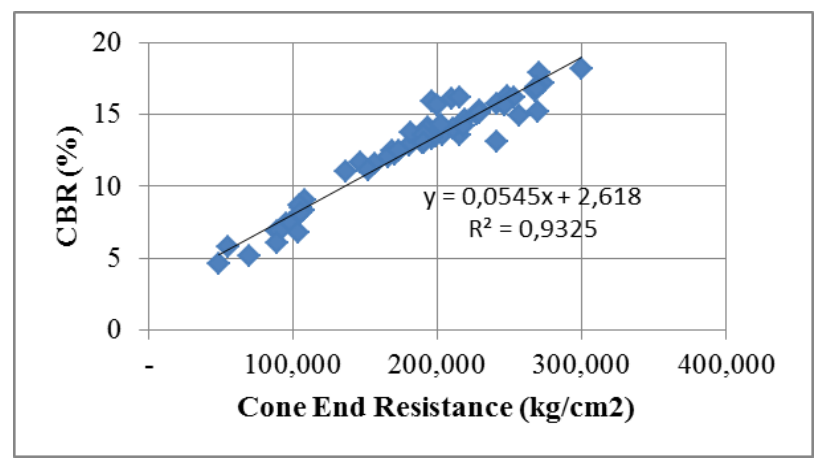

Gambar 6 Hub CBR dan Tahanan Ujung Konus di Banjarbaru

\section{PENUTUP}

\section{Kesimpulan}

1. Penentuan harga CBR dengan menggunakan uji konus merupakan cara yang paling praktis dibandingkan dengan cara yang lain.

2. Sudah ada beberapa penelitian mengenai hubungan CBR dan $\mathrm{q}_{\mathrm{c}}$, namun belum tentu bisa diaplikasikan di semua daerah.

3. Untuk daerah Banjarbaru hubungan antara CBR dan $\mathrm{q}_{\mathrm{c}}$ dinyatakan dengan rumus $\mathrm{CBR}=$ $0,0545 \mathrm{q}_{\mathrm{c}}+2,618$

\section{DAFTAR PUSTAKA}

Arief TD, Markopolo, Krislinawati SH. Model Korelasi Antara Cc Dengan Ll Untuk Tanah Lempung Di Surabaya. Dimens Tek Sipil. 2002;4(1):9-14.

ASTM. ASTM 1883-87 Standard Test Methods for Laboratory CBR Test. Annual Book of ASTM Standart Construction. 1989.

ASTM. ASTM D- 4318 Standard Test Methods for Liquid Limit, Plastic Limit and Plasticity Index of Soil. Annual Book of ASTM Standart Construction. American Society for Testing and Material; 1989.

ASTM. ASTM D- 854 Standard Test Methods for Specific Gravity of Soil Solid. Vol. 1, Annual Book of ASTM Standart Construction. Annual Book of ASTM Standart Construction; 1989. 368-376 p.

Bakrie O, Gofur N. Sifat-Sifat Tanah Dan Metoda Pengukurannya. Palembang: Universitas Sriwijaya; 1995.

Bowles J. Engineering Properties of Soil and Their

Measurement. 4th Editio. New York: Megrow-Hill; 1992.

Budiman NA. Pengaruh Penambahan Abu Ampas 
Tebu Terhadap Sifat Fisik Dan Sifat Mekanik Tanah Lempung Ekspansif. J Ilm Tek Sipil. 2013;17(1):84-96.

G.M A, O.A A. Influence of Inorganic Salts on Soils Liquid and Plastic Limits. Civ Eng Dimens. 2013;15(1):51-60.

Hardiyatmo H. Mekanika Tanah I. Edisi Keem. Yogyakarta: Gajah Mada University Press; 2006.

Marwan, Sundary D. Hubungan Nilai California Bearing Ratio Dengan Indeks Plastisitas Tanah Desa Neuheun Aceh Besar. J Tek Sipil Univ Syiah Kuala. 2012;2(September 2012):97-104.

Nasrullah O. Pengaruh Sodium Hidroksida $(\mathrm{NaOH})$ Sebagai Bahan Stabilisasi Terhadap CBR rendaman dan Batas-batas Konsistensi Tanah Lempung Bukit Rawi. Universitas Muhammadiyah Palangkaraya; 2010.

Purnomo M. Korelasi Antara CBR, PI Dan Kuat Geser Tanah Lempung. J Tek Sipil dan Perenc. 2011;13(1):81-90.

Rahardjo. Uji Sondir: Interpretasi Aplikasinya Untuk Perencanaan Pondasi. 1996.

Rostikasari A, Surjandari NS, Djarwanti N. Korelasi Indeks Kompresi (CC) Dengan Parameter Kadar Air Alamiah (wn) Dan Indeks Plastisitas ( IP ). e-Jurnal MATRIKS Tek SIPIL. 2016;55:570-5.

Shalahuddin M. Varian CBR Yang Mewakili Terhadap Kedalaman Uji DCP. J Aptek. 2012;4(2):65-70.

Widari LA. Pengaruh Penambahan Pasir Pada Tanah Lempung Terhadap Kuat Geser Tanah. Teras J. 2015;5(2):144-52.

Zaro K, Nugroho S, Fatnanta F. Pengaruh Kadar Lempung Dengan Kadar Air Diatas OMC Terhadap Nilai CBR Dengan Dan Tanpa Rendaman Pada Tanah Lempung Organik. Jom F Tek. 2014;1(2):1-5. 